Article

\title{
Establishing the Regional Sustainable Developmental Role of Universities-From the Multilevel-Perspective (MLP) and Beyond
}

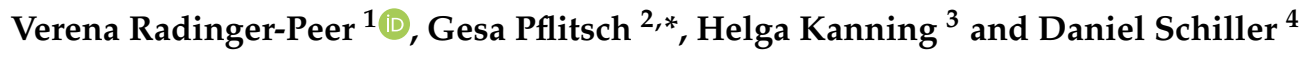 \\ 1 Department of Economics and Social Sciences, University of Natural Resources and Life Sciences Vienna, \\ 1180 Vienna, Austria; verena.radinger-peer@boku.ac.at \\ 2 Department of Geography, Philipps-University Marburg, 35032 Marburg, Germany \\ 3 Sustainify $\mathrm{GmbH}$, Hanover and Institute of Environmental Planning, Leibniz University Hannover, \\ 30419 Hanover, Germany; kanning@umwelt.uni-hannover.de \\ 4 Institute of Geography and Geology, University of Greifswald, 17489 Greifswald, Germany; \\ daniel.schiller@uni-greifswald.de \\ * Correspondence: gesa.pflitsch@staff.uni-marburg.de
}

Citation: Radinger-Peer, V.; Pflitsch, G.; Kanning, H.; Schiller, D.

Establishing the Regional Sustainable Developmental Role of

Universities-From the

Multilevel-Perspective (MLP) and

Beyond. Sustainability 2021, 13, 6987.

https://doi.org/10.3390/su13136987

Academic Editor: Clemens Mader

Received: 29 April 2021

Accepted: 26 May 2021

Published: 22 June 2021

Publisher's Note: MDPI stays neutral with regard to jurisdictional claims in published maps and institutional affiliations.

Copyright: () 2021 by the authors. Licensee MDPI, Basel, Switzerland. This article is an open access article distributed under the terms and conditions of the Creative Commons Attribution (CC BY) license (https:// creativecommons.org/licenses/by/ $4.0 /)$.

\begin{abstract}
This article establishes the multilevel perspective (MLP) as one of the main research approaches in transition research to study complex systemic change processes in socio-technical systems at different structural levels. The application of the MLP to the higher education system, especially to conceptualize the transition of universities towards a sustainable (regional) developmental role, is still in its infancy. Through using a descriptive narrative analysis of seminal articles, the results of the four-years cooperation within an expert working group, and own empirical findings, the present paper investigates the suitability of the MLP to study the transition of universities and university systems towards a sustainable developmental role in the regional context. Based on these investigations, three further perspectives (which must be considered for establishing a more comprehensive understanding of the universities' sustainable developmental role) are identified and conceptualized: (a) The target dimension of sustainable regional development, (b) the role of agency, and (c) the introduction of space and place to multiscalar regional transitions. Based on these perspectives, a future research agenda beyond the MLP is developed.
\end{abstract}

Keywords: sustainable developmental role; regional sustainable development; higher education; multilevel perspective; agency; place and space; universities

\section{Introduction}

It was in the 1980s when claims regarding the regional engagement of universities first arose in regional policy [1]. Scientific efforts investigating the role of universities in regional development have, thus far, produced two major streams of literature enlightening the 'generative' and 'developmental' role of the universities [2]. The former entails the role of universities in promoting regional economic activities through academic entrepreneurialism (e.g., triple helix model, entrepreneurial university) [3,4]. The latter refers to a broader understanding of university engagement through formal and informal participation in networks, collective action, and knowledge co-production whereby the university interacts with broader regional governance structures (e.g., engaged university, civic university) [5,6]. A significant part of universities' potential to promote development lies in the fact that they are generally not purely regional bodies, but exhibit a multiscalar character that seeks to integrate the global with national and regional scales [7]. In doing so, they translate global developments to the local and regional scale by localizing elements of both, "local nodes" and "global networks" [8]. One example for this is the concept of sustainable development, elaborated by the Brundtland Report "Our Common Future" in 1987 [9] and declared the guiding principle for the development of "environment and society" in the 21st century by 
"Agenda 21", signed by the international community at the Earth Summit in Rio de Janeiro in 1992 [10].

Alongside developments at the global level, from the 1992 Earth Summit in Rio until the formulation of the Sustainable Developments Goals by the UN in 2015 [11], the advancement of sustainable development in higher education has shifted from a 'sustainability in higher education' phase towards 'higher education for sustainable development'. The former entails mainly the integration of sustainability in university management practices [7,12], corporate social responsibility, sustainability reporting, and accounting [13-15], while the latter expands the activities of universities in the field of sustainable development towards (i) teaching and education for sustainable development [16-18]; (ii) generation and advancement of scientific knowledge and other forms of knowledge [19,20]; (iii) boundary spanning, participation in regional sustainability initiatives and networking [17,21,22]; and (iv) applying sustainability as an overall concept for universities as in, for example, the 'sustainable university' [23,24].

'Higher education for sustainable development' is, thus, characterized by knowledge production via collaborations with external stakeholders $[17,25,26]$, and an increasing focus on the surrounding society with a geographical focus on the immediate communities and regions [27]. It demands that universities take on a sustainable developmental role [2,21] which entails, for example, the integration of regional needs into teaching and research, the development of long-term strategic visions and goals [26], bridging different types of knowledge through inter- and transdisciplinary approaches [23,28,29], assuming a boundary spanning role [21], and strengthening the regional collaborative capacity [30].

The region takes on central importance as an arena for action for the joint development of solutions (co-creation) for the major societal challenges. The immediate spatial reference creates important preconditions for joint action by actors from the fields of science, business, society, and politics [31]. Thereby regional actors are important agents of change who can influence the transformation of the university. While the role of universities for regional development has been studied throughout the last decade from various perspectives, e.g., their role in regional innovation systems or within the triple-helix model of university-business-government cooperation (e.g., for a comprehensive literature review see, Arbo and Benneworth [7]), there is yet a dearth of knowledge on how universities can establish a sustainable developmental role and in addition to the impact on the sustainability transitions of their region and which organizational and institutional changes within and outside the university deem necessary to establish this role. The complexity of this endeavor is underlined by the fact that, on the one hand, sustainability is an evolving and moving target [32], and on the other hand, the university is a multifaceted, multiscalar, and loosely coupled organization and challenged by processes of organizational change and learning [32,33].

How sustainability transformations, in general, takes place is the focus of sustainability transition research. Transferring approaches from sustainability transition research to the higher education system makes it possible to examine not only partial aspects of the activities of a specific group of actors, but also the interaction of various elements in the context of a systemic transformation of the higher education sector see also [34,35]. The multilevel perspective (MLP) of Arie Rip and Rene Kemp [36], which was significantly further developed by Frank Geels [37,38], is a suitable analytical framework and one of the main research approaches in transition research $[39,40]$. MLP offers a heuristic to capture complex systemic change processes in socio-technical regimes at different structural levels $[38,39]$. A basic assumption of this approach is that radical innovations emerge in so-called niches that are protected by the existing selection criteria of established regimes. The further framework conditions in which niches and regimes are embedded are described by the landscape level. A major contribution of MLP is that it introduces the linkage and mutual influence of processes in the different dimensions to explain transitions ('circular causality'), and thus, overcomes simplistic causalities or the isolated consideration of individual driving forces [41]. 
Taking into account that the higher education system is still characterized by highly pronounced disciplinary cultures, compartmentalization, increasing competition (for students, funding, and prestige), performance measurements, and rankings, all of which inhibit the establishment of a sustainable developmental role, the present paper enlightens the following research questions: (1) To what extend is the MLP suitable to conceptualize the transition of universities towards a sustainable (regional) development role? Which limitations exist and which specifications are necessary? (2) What is the target dimension for the sustainable (regional) developmental role of universities? How can it be achieved? (3) Which additional aspects should be considered (beyond the MLP) for establishing a more comprehensive conceptual understanding of the sustainable (regional) developmental role of universities?

The present paper is based on a comprehensive literature review, as well as research results gained within the ARL (Academy for Territorial Development in the Leibniz Association) working group on "Universities and sustainable regional development" [42,43].

To answer these questions, the paper is structured as follows. Section 2 describes the methodological approach. Section 3 focuses on the state of research on higher education from a multilevel perspective and discusses limitations and necessary specifications. Section 4 introduces the target dimension for the sustainable (regional) developmental role of universities and provides considerations regarding its establishment based on the MLP. Section 5 takes the discussion beyond the MLP and introduces elements of a future research agenda on the sustainable (regional) developmental role of universities with a particular focus on agency, as well as space and place. Section 5 discusses the findings and further concludes.

\section{Methodological Approach}

The present paper is based on three sources of information: (a) A descriptive narrative analysis of seminal articles, (b) a four year cooperation of the authors within the Working group "Universities and sustainable regional development" of the ARL-Academy for Territorial Development in the Leibniz Association, Germany and (c) own empirical case study research, focusing especially on the Johannes Kepler University in Linz, Austria [21,44], and the University of Augsburg, Germany [21,45].

(A) Descriptive narrative analysis of seminal articles: Due to former research and publications of the authors, they are well informed about and anchored in the following research areas: The role of the university in regional development, sustainability in higher education, the multilevel perspective and sustainability transition research (see Figure 1). While each of these areas is based on a rich empirical and theoretical basis, research on the role of $\mathrm{HE}$ for sustainable development from a multilevel perspective is still in its infancy. An investigation of the literature via Web of Science and SCOPUS using the keywords "sustainability + higher education + multilevel perspective" led to two recent publications. Furthermore, the Ph.D. publication by Hume [35], was known to the authors. A descriptive narrative analysis was conducted, whereby the focus was on the conceptualization of the developmental role considering the five spheres teaching, research, outreach, operation, and governance, as well as the interrelations between the three levels niche, regime, and landscape.

(B) ARL Working group "Universities and sustainable regional development": Throughout a timespan of four years, 18 experts from the field of Higher Education and regional development, mainly from Germany and one researcher from Austria, cooperated to share experiences, expertise and conceptualize this topic. The working group started a forum, wherein the authors have been able to present their work, and critically reflect on it.

(C) Empirical research: Two authors conducted empirical research on the topic of interest $[21,43,44]$, which allowed them to review and reflect the findings, conceptualizations, and conclusions of the current paper. 


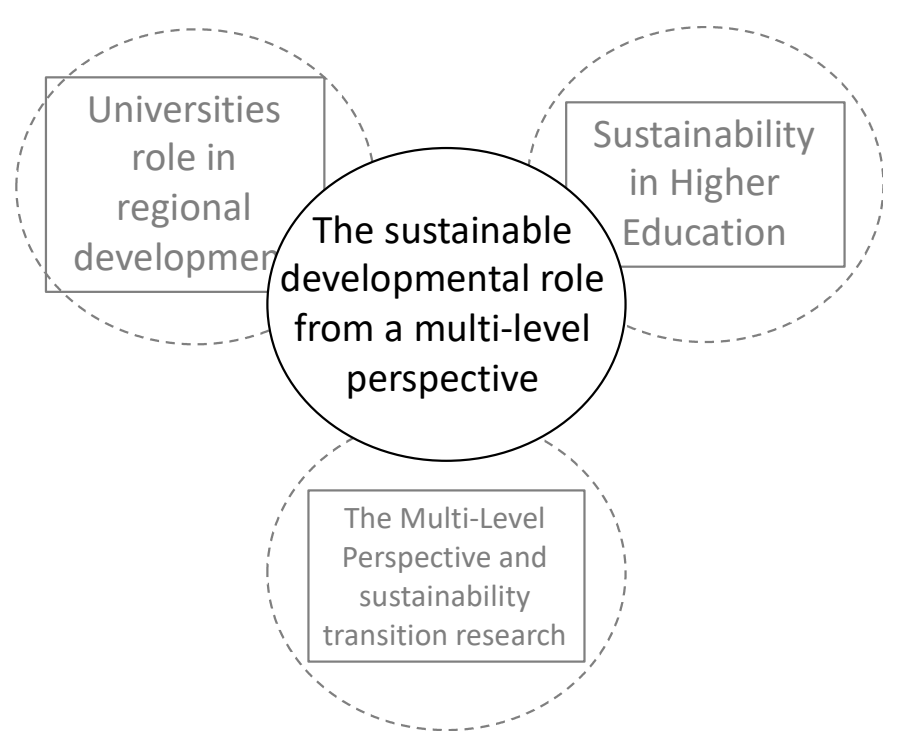

Figure 1. Positioning the focus of the paper in the existing state of research (own illustration).

\section{Application of the Multilevel Perspective (MLP) to Higher Education (RQ1)}

\subsection{State of Research}

The application of the MLP to higher education institutions (HEIs) and higher education systems is still in its infancy. Compared to other socio-technical systems such as the energy or mobility systems, there are still very few studies with this orientation. In their article, Stephens and Graham [34] already pointed out the potential of such a perspective for the analysis of a fundamental transformation of the higher education system. Based on the transition management framework, they formulated a corresponding research agenda [34]. However, very few studies since then have conceptually and empirically addressed the question of how the whole higher education system needs to transform for HEIs to contribute to a broader societal transition. Initial projects, and respective publications, have, however, appeared in the form of journal articles and Ph.D. projects. Most notable are the work of Hume [35] and Deleye et al. [46], both of which draw on the MLP. While Hume [35] compares transformation processes at two HEIs embedded in different higher education systems (Northern Ireland, Republic of Ireland), but influenced by similar landscape trends, Deleye et al. [46] analyze the embedding of the sustainability topic in the Flemish higher education system.

The starting point of each of these papers is the application of the three MLP levels (regime, niche, landscape) to the higher education system. The regime level is understood as the dominant structures, practices, as well as prevailing culture in the higher education system, which includes the expectations of policymakers and students [34,46]. Niches are seen as spaces where innovative, more sustainable practices are experimented with. These often emerge within HEIs or at the interface between HEIs and their regional environments [46]. However, niches can also encompass entire HEIs or other (cross-sectoral) organizations (e.g., international associations such as the Association for the Advancement of Sustainability in Higher Education (AASHE)) (global niches; [34,35]). At the landscape level, in addition to higher education policy, a whole spectrum of policy fields, as well as broader societal and environmental trends (e.g., climate change, globalization), are located $[35,46]$.

A key finding of the above-mentioned empirical studies is that the higher education system has some distinctive features; some of which are classified as conducive, others as rather obstructive to a transition to sustainability $[35,46]$. For example, the landscape level in the higher education sector is particularly diverse, as HEIs influence and are influenced by many other regimes through their research [35]. Moreover, the regime in the higher education sector is described as very heterogeneous and varied (see also Table 1). The 
response of individual HEIs to developments at the landscape level (e.g., national laws and policies) can, therefore, vary widely, according to Hume [35].

Table 1. Particularities of higher education systems and their consequences for transformation capacity (own compilation).

\begin{tabular}{|c|c|c|c|}
\hline \multirow{2}{*}{ Level } & \multirow{2}{*}{$\begin{array}{l}\text { Particularities of Higher } \\
\text { Education Systems }\end{array}$} & \multicolumn{2}{|c|}{ Consequences for Transformation Capacity } \\
\hline & & Positive & Negative \\
\hline Landscape & $\begin{array}{c}\text { freedom of research } \\
\text { and teaching } \\
\text { subject-specific traditions }\end{array}$ & processes are less aligned & $\begin{array}{l}\text { contradictory influences } \\
\text { (e.g., academic excellence } \\
\text { vs. civic engagement) } \\
\text { fragmentation of } \\
\text { knowledge on } \\
\text { transformations }\end{array}$ \\
\hline Regime & $\begin{array}{l}\text { guiding principles } \\
\text { (e.g., entrepreneurial university) } \\
\text { weakly developed } \\
\text { hierarchies } \\
\text { 'loosely coupled systems' } \\
\text { global 'epistemic } \\
\text { communities' }\end{array}$ & $\begin{array}{l}\text { lower rigidity of } \\
\text { the regime } \\
\text { leeway within the regime } \\
\text { niche-regime interaction } \\
\text { high degree of } \\
\text { internationalization }\end{array}$ & $\begin{array}{l}\text { self-referential evaluation } \\
\text { and reproduction system } \\
\text { reputation criteria } \\
\text { 'ivory tower' } \\
\text { role of gatekeepers }\end{array}$ \\
\hline Niche & $\begin{array}{l}\text { high degree of autonomy at } \\
\text { the level of individual } \\
\text { researchers and } \\
\text { working groups }\end{array}$ & $\begin{array}{l}\text { bottom-up dynamics } \\
\text { experimentation in } \\
\text { established structures } \\
\text { regional cooperation in } \\
\text { research, teaching, } \\
\text { and transfer }\end{array}$ & $\begin{array}{c}\text { lack of bundling } \\
\text { of activities } \\
\text { barriers to up-scaling }\end{array}$ \\
\hline
\end{tabular}

In this context, Hume [35] also addresses the criticism in the transition literature that the changeability of regimes is often underestimated, and the regime is assumed to be rigid. In her view, the adaptability ('adaptive capacity'; [35] (p. 87)) of a regime (institutional flexibility, resources committed to innovation) can be influenced, precisely because in the higher education sector, learning and innovation are generally given great importance and spaces are created for that purpose. Stephens and Graham [34] and also Deleye et al. [46] argue in a similar direction. They assume that universities, in particular, have the potential for a transition, due to their "unique learning culture" [34] (p. 613), as well as freedom of research and teaching.

At the same time, however, previous studies also pointed out that the fragmented organizational structure of universities and firmly established academic conventions/traditions pose a challenge for such a transition [34,35]. Deleye et al. [46] highlight financial scarcity, strong competition between HEIs and also between individual academics, and a focus on technological innovation, among others, as obstructive regime characteristics. At the same time, they also point to contradictions and tensions in the higher education regime that could destabilize the regime, and thus, provide entry points for change (such as the increasing number of students vs. limited investment in higher education or the monodisciplinary structures vs. the recognition of complexity).

\subsection{Limitations and Specifications}

Based on the comprehensive literature review, the particularities of higher education systems are summarized from an MLP perspective in Table 1, and positive and negative consequences regarding the transformation capacity of universities and the higher education system are elaborated. The MLP perspective on transformation processes was developed primarily for the analysis of so-called socio-technical systems. However, the higher education system in general, as well as individual HEIs and groups of HEIs, in particular, possess a large number of specific features that limit the applicability of the standard MLP model and require a more precise definition. Table 1 lists some of these particularities and assesses them in terms of their consequences for the ability to transform 
higher education towards the 'sustainable developmental role'. These are described in more detail below.

The landscape level of HEIs is particularly diverse. While the freedom of science and teaching is a common characteristic [42], there are numerous subject-specific traditions that influence values, norms, research attitudes, etc. Furthermore, In addition to fundamental trends related to HEIs, broader societal developments, and events must also be taken into account (e.g., climate change, economic crises, etc.), which encompasses a broad spectrum of other policy fields in addition to direct higher education policy [35]. While these heterogeneous and flexible characteristics of the HEI landscape have positive effects on its transformation capacity, negative influence is exerted via contradictory claims (e.g., academic excellence vs. civic engagement), as well as knowledge fragmentation.

Universities influence many other regimes through their research and are also influenced by them in turn. Each individual HEI is seen by Hume [35] as a regime actor. However, the regime in the higher education sector is characterized by heterogeneity and diversity. Thus, the response of individual HEIs to developments at the landscape level (e.g., national laws and policies) can vary greatly. Within individual disciplines, regimes are structured by global 'epistemic communities'. Weick [47] describes universities as "loosely coupled systems". Within the university, the university management has only limited control potential. Faculties, disciplines, and individual academics or working groups are free to decide on the content and focus of their research and teaching and on various organizational aspects. The low rigidity, as well as existing leeway within the regime, have a positive influence on the transformation capacity. In addition, the strong international orientation of regime structures, can have a positive effect on the ability of individual universities to change [48], but can also create new rigidities in the form of powerful gatekeepers. Within global 'epistemic communities', a potential tradeoff exists between an in-depth interaction with stakeholders and practitioners in the local context and the valuation of research by scientific peers at the global level, supporting a self-referential evaluation and reproduction system.

With regard to the niche level, Individual academics, for example, have the opportunity to establish a sustainability-oriented research program within existing regime structures, due to their high autonomy. A further positive aspect with regard to the transformation capacity is the possibility to experiment within established structures, as well as to engage in regional cooperation (via teaching, research, and transfer). On the other hand, many of these activities remain fragmented and unconnected [21,44], and are confronted with the challenge to up-scale.

Initially, theory building in MLP was strongly focused on "bottom-up" transition dynamics and potentially more sustainable technologies, which was also underlined by research on Strategic Niche Management (SNM). This is based on the assumption that niche activities can break through and replace the regime at an opportune moment [38]. However, Geels [38] already pointed out in his early publications that transitions come about through the dynamic interaction of all three levels.

The questions on how dynamics of transformations can be grasped and which directions they can take have evoked a number of typologies. Within the wider frame of the MLP, Geels, and Schot [49] differentiate between four different transition pathways, which are characterized by the timing of changes at niche and landscape level and their relationship to each other (cooperative or competitive), as well as by different dynamics within the socio-technical regime [50]: More moderate pathways such as 'regime transformation', and 'regime reconfiguration', result from less urgent landscape pressure. On the other hand, 'technological substitution' occurs when a well-developed niche can exploit the weaknesses in a regime-under-pressure and grow to replace the regime. The fourth pathway, 'dealignment and realignment', is where the regime is eroded by extreme landscape pressures. Hume [35] refers to the transition topology provided by De Haan and Rottmans [51] when studying sustainability in HEIs. This typology is based on the dominant direction and magnitude of forces and differentiates between reconstellation-driven (top-down), empow- 
erment (bottom up) driven, squeezed (combination of reconstellation and empowerment), and adaptation pathways. There is no investigation known to the authors, which would enlighten the question of transition pathways for HEIs.

Overall, the literature shows that analyzing the higher education system from the MLP is profitable, but also requires adjustments and extensions. This becomes particularly true when the MLP is not only applied to discuss "sustainability in HE" [35,46], but especially when the focus is on 'higher education for sustainable development' and (as in this paper) on 'sustainable regional development'.

While the previous statements elaborated on the transfer of the MLP to the higher education system, it deems necessary that the perspective is broadened to the transmission of the MLP on the transformation towards a sustainable developmental role. Three perspectives, which have already been discussed in the context of a more general critical examination of MLP [39,52-54], become particularly visible/relevant when the approach is transferred to a social system such as the higher education system: (1) The hitherto little addressed/specified target dimension of sustainability transitions [46]; (2) the neglect of agency in favor of a focus on systemic processes [35]; and (3) the lack of spatial reference of MLP.

First, with regard to the target dimension, sustainability is an evolving and moving target [32]. This is in line with [46] who remark that the idea of what a sustainable higher education system can/should look like is very vague and broad. The necessity to shed more light on the target dimension of such a transformation in future studies is highlighted several times in the literature. In this context, higher education institutions have the potential to bring together heterogeneous actors and discourses, even across different spatial levels (and thus, to become local-global nodes [35]. However, an orientation of the higher education system should not be understood as 'dogmatic', but should be seen as flexible and designable. Permanent reflection and learning processes at different levelsespecially within the regional context-are necessary [35]. The specific design of the target dimension in the context of sustainable regional development will be addressed in detail in Chapter 3.1 of this contribution.

Second, most existing studies that explicitly focus on the role of universities in regional sustainability transitions show that universities need to interact with a more diverse range of regional actors-including actors from the economy, the public field, and civil society $[25,26]$. Thereby the (sustainable developmental) role must be seen as the outcome of complex process dynamics which are shaped by intended and unintended action of multiple actors from both the university and the region over time. As such, a more detailed investigation of the agency deems necessary.

Third, although spatial processes are mentioned in this context, the differentiated discussion on the geography of transitions $[55,56]$ has not yet found its way into research on HEIs and MLPs. Based on findings from this research field, it can be assumed that higher education institutions and their spatial environment mutually influence their transformation and that these processes are, thus, "place-specific" [21]. The complex multiscalar dynamics of sustainability transitions, which have been elaborated in geographical transition research $[57,58]$, are also not examined more closely in previous research on higher education institutions and MLPs.

Figure 2 frames the results derived from state of the art (left side, Section 3) and especially emphasizes the core contribution of the paper, that is the, target dimension of sustainability transitions (see Section 4.1), as well as a definition of the sustainable developmental role (see Section 4.2). For this purpose, we propose a structuring of the regime level based on five subsystems. 


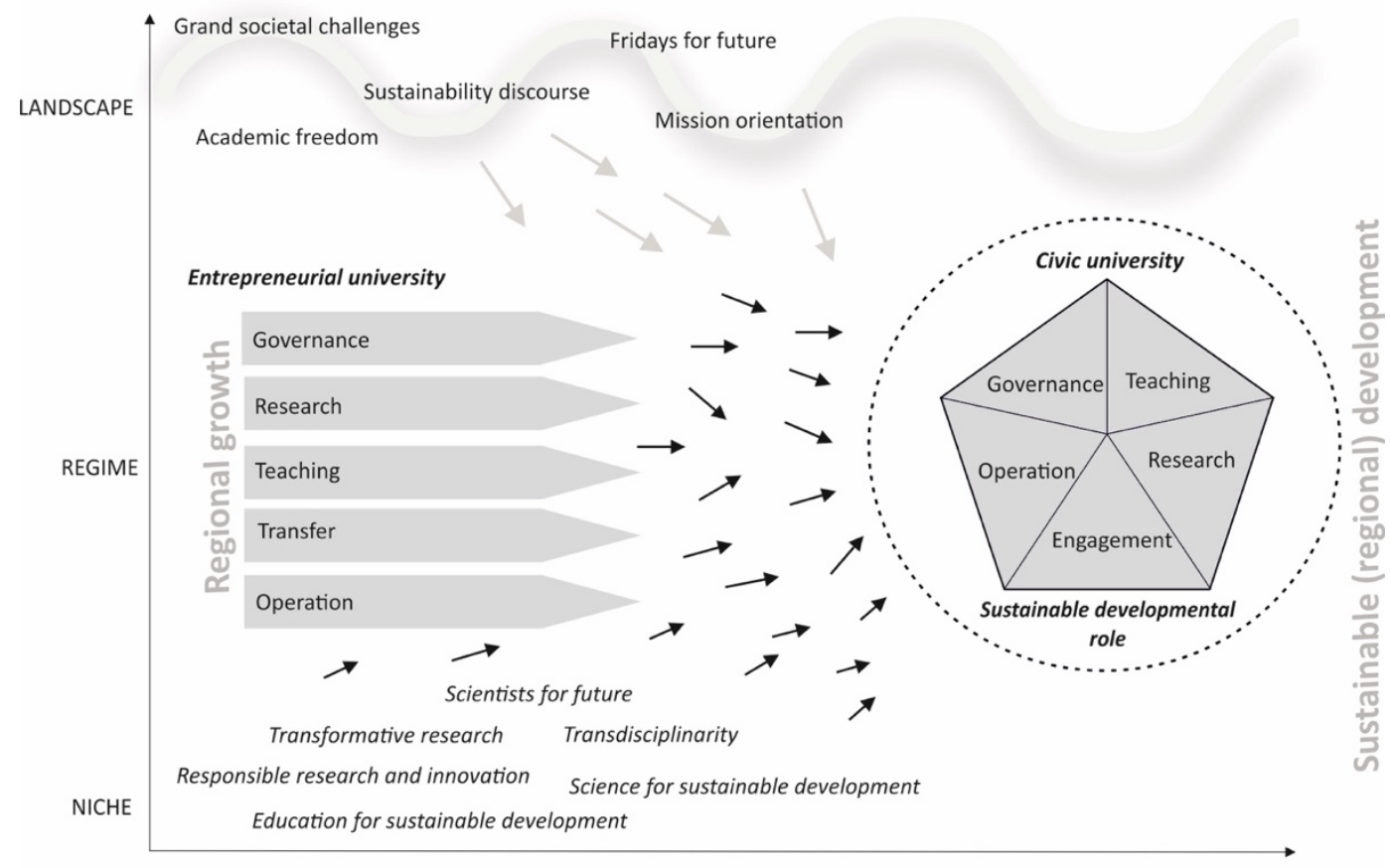

Figure 2. Multilevel transition of higher education universities towards a sustainable development role (Source: own draft).

\section{Conceptualization of the Sustainable Developmental Role of Universities and HE (RQ2)}

The subsequent chapter addresses the abovementioned gaps and provides a conceptual lens on how to grasp and frame the sustainable developmental role of universities in the regional context. In doing so, it elaborates on the target dimension of sustainable regional development and provides a definition of the sustainable developmental role (see also Figure 2).

\subsection{Target Dimension of Sustainable Regional Development}

In order to be able to conceptualize the sustainable developmental role of universities, it is necessary to reflect on the target dimension of "sustainable development" as also demanded in the literature [32,46]. How can we formulate a target scenario (Figure 2, right part) in which universities play a leading role in the transformation to sustainability at the regional level? To answer this question, we combine two fields of research that have so far been largely separate: First, the discourses around the vision and implementation of sustainable regional development; second, those on sustainable higher education/academia. The 'sustainable (regional) developmental role' of higher education institutions emerge from the merging of these two discourses, as the authors of [42] discuss.

\subsubsection{Sustainable Regional Development}

Discussions on the definition and design of sustainable regional development are still ongoing. From the abundance and diversity of material available in the subject area, we represent an overarching approach that encompasses the dimensions of ecology, economy, and social issues. In spatial planning and planning science, the discussion on implementing the sustainability guiding principle was conducted early on, roughly from the mid-1990s until the first decade of the 2000s. Summary overviews of the development and state of the discussion are provided in particular by Spehl [59] and Hofmeister [60,61], as well as Hübler et al. [62] and Stuckrad et al [63]. Table 2 summarises key contents, deficits, and challenges from the debate; for further details, please refer to Schiller, Kanning et al. [42]. 
Table 2. Dimensions and challenges for sustainable spatial and regional development (own compilation in: [42] (p. 136), translated).

\begin{tabular}{|c|c|}
\hline Dimension & Contents, Deficits and Challenges \\
\hline Substantial & $\begin{array}{l}\text { Sustainability concept is still vaguely defined } \\
\text { Human needs form orientation framework } \\
\text { Integration imperative requires integrative consideration of the three dimensions ecology, economy, } \\
\text { and society } \\
\text { Ecological economics offers scientifically based explanations for the significance of the ecological } \\
\text { system as a necessary basis of life for the economy and society } \\
\text { Physical dimensions of economic activity (material and energy flows) form interface between ecology, } \\
\text { economy, and society } \\
\text { Efficiency, sufficiency, and consistency are complementary, strategic guiding principles } \\
\text { SDGs provide a political-normative framework; ecological carrying capacities/planetary boundaries } \\
\text { should be considered }\end{array}$ \\
\hline Procedural & $\begin{array}{c}\text { Sustainable regional development is a continuous social search, learning, and understanding process } \\
\text { Cooperation and networks are keystones } \\
\text { (Regional) Governance discussion is connectable }\end{array}$ \\
\hline Actor-related & $\begin{array}{c}\text { Spatial planning offers competencies for the organization of continuous social search, learning, and } \\
\text { understanding processes, as well as for determining ecological carrying capacity/planetary } \\
\text { boundaries, but has so far played a subordinate role in regional processes } \\
\text { Companies have so far been insufficiently integrated into sustainable regional development } \\
\text { processes/economic cycles } \\
\text { The role of universities has so far been viewed mainly from an economic perspective, but not } \\
\text { systematically investigated with regard to sustainability }\end{array}$ \\
\hline Spatial & $\begin{array}{l}\text { Regions are important levels of action; in addition, the politically constituted municipal level also } \\
\text { plays a significant role (Local Agenda } 21 \text { initiatives) } \\
\text { Spatial boundaries of regions are variable, sustainable regions are mainly characterized by regional } \\
\text { actor networks (open/actor-centered concept of the region) } \\
\text { Regional economic cycles imply a balancing act between globalization and regionalization }\end{array}$ \\
\hline Temporal & $\begin{array}{l}\text { Principle of justice requires in the sustainability model requires } \\
\text { Inclusion of the time factor } \\
\text { Long-term considerations }\end{array}$ \\
\hline
\end{tabular}

As elaborated by Schiller, Kanning et al. [42], and compiled in Table 2, sustainable regional development is characterized, for example, by the following dimensions: (a) Substantial (human needs form the orientation framework, integrative consideration of the three dimensions ecology, economy, and society); (b) procedural (sustainable development as continuous social search, learning, and understanding process whereby cooperation and networks are cornerstones); (c) actor-related (especially actors such as enterprises and universities are yet not systematically integrated and investigated); (d) spatial (regions as important levels of action but also regional actor networks); (e) temporal (long-term considerations). In summary, it can be stated from the discussions associated with this and the general debate on guiding principles that there is a consensus that sustainable regional development is shaped differently from region to region, depending on the respective natural and socio-spatial endowments and actor constellations of a region, and is characterized by continuous social search, learning and communication processes.

\subsubsection{Sustainable Universities/Science and Their Contributions to Sustainable Regional Development}

A wealth of material also exists on the topic of sustainable universities/science, but it generally does not yet include spatial contexts [42]. In 1992, Agenda 21 already assigned universities a special responsibility for shaping sustainable development processes in chapters 31 and 35 . On the national level, the WBGU explicitly refers to the central role of universities and science in providing targeted support for the knowledge-based societal search processes for sustainability with research and education, and proposes further far-reaching developments. It recommends a "transformative quartet of the knowledge society" [64] that establishes and interlinks both targeted research and education on 
transformation processes (transformation research, education) and their active co-design (transformative research, education). To this end, a new interplay between politics, society, science, and business is called for [64].

Thus, it seems sensible to characterize the regime based on five areas, to which importance is also attributed in this context. First of all, these include the two core tasks of research and teaching. In addition, the third mission, which is increasingly gaining in importance, is an important area of responsibility that has extensive overlaps with the term transfer [65], and in the status quo is often still practiced in the less comprehensive and linear form as a transfer. In addition, the operation and governance of higher education institutions are also significant. These five areas can be seen as sub-regimes of the higher education system (see Figure 1).

Table 3 summarizes the main features of the many contributions to the discussion on these five fields of action in particular from [64,66-70]. In addition, the contributions are supplemented on the one hand by the knowledge on sustainable regional development outlined above (see Table 2) and on the other hand by knowledge on the transformation field of third mission/transfer based on the systematics of Henke et al. [71] and from the German Council of Science and Humanities [65].

Universities can scientifically accompany the necessary social search, learning, and understanding processes and thereby become effective both substantially and procedurally. Substantive contributions arise because universities bring the integrative perspective (ecology, social, economy) into regional development, demand and support the fulfilment of complementary sustainability strategies (efficiency, sufficiency, consistency) and contribute to the negotiation of ecological carrying capacities/guidelines. Procedural contributions lie in the fact that universities, on the one hand, pursue a recursive knowledge transfer as mutual knowledge transfer and production between the university and regional actors, with the goal of co-production of knowledge or an 'ownership of knowledge and values'. On the other hand, they can act as 'brokering' and 'bridging organizations' by bringing together different actors involved in the sustainability process (state, economy, civil society) and mediating between regionally and globally significant knowledge, or by taking on an interpretive role and communicating knowledge about sustainability and the associated contexts to non-scientific target groups [42] (see Table 3).

Table 3. Characteristics of a sustainable developmental role of universities (own compilation in: [42] (p. 155) translated and adjusted).

\begin{tabular}{cl}
\hline Field of Action & \multicolumn{1}{c}{ Characteristics } \\
\hline & Transformational, transformative research in/with the region through \\
& Inter- and transdisciplinary, participatory research, co-production of knowledge (co-creation of \\
knowledge for sustainability) & Integrative, systemic perspective with special attention to the co-evolution of complex systems and \\
their environment & Contributions to solutions for societal challenges and Sustainable Development Goals (SDGs), \\
& "Research in social responsibility" (e.g., LeNa reflection framework for Germany) \\
& Transformational, transformative education in/with the region through measures for students: \\
& Teaching design and key competencies. \\
& Learning through experimentation, explorative, reflexive learning \\
& Imparting knowledge of goals and transformation based on systems knowledge \\
& Measures for teachers: \\
& Development of courses on the topic of sustainability, imparting sustainability competencies \\
& for teachers \\
\hline
\end{tabular}


Table 3. Cont

\begin{tabular}{|c|c|}
\hline Field of Action & Characteristics \\
\hline $\begin{array}{l}\text { Third Mis- } \\
\text { sion/transfer/engagement }\end{array}$ & $\begin{array}{l}\text { Recursive, sustainability-related knowledge transfer/exchange with society and business in/with the } \\
\text { region through } \\
\text { Knowledge transfer between science, civil society, politics, and business; intensive exchange with and } \\
\text { involvement of societal actors (universities as 'brokering', 'bridging organizations', contribution of } \\
\text { sustainability knowledge (incl. integrative view, complementary strategies) } \\
\text { Knowledge marketing: Marketing of university sustainability-related knowledge resources } \\
\text { Sustainability-related continuing education (professional, academic) } \\
\text { Transfer projects, partnerships with explicit sustainability reference } \\
\text { Consulting: Political advocacy in favor of sustainability; public statements, expert opinions, etc. } \\
\text { Social engagement (civic engagement, community services (e.g., participation in Local Agenda } 21 \\
\text { processes, regional sustainability initiatives) } \\
\text { Widening participation: Promotion of previously underrepresented groups }\end{array}$ \\
\hline University operations & $\begin{array}{l}\text { Sustainable university operations in/with the region through } \\
\text { Operational environmental management for universities (EMAS) } \\
\text { Supporting processes, e.g., procurement, mobility management } \\
\text { Environmental/sustainability reporting, German Sustainability Code (DNK) for universities }\end{array}$ \\
\hline University governance & $\begin{array}{l}\text { University governance in exchange with the region ('Civic University') through: } \\
\text { Basic principles: Good governance, responsible use of resources } \\
\text { Social commitment and sustainable development as maxims guiding action } \\
\text { Implementation of strategic sustainability management as a dynamic and continuous process } \\
\text { Systematic, participative integration of the sustainability topic into the university, including visions } \\
\text { and guiding principles } \\
\text { Creating incentives for transformation, e.g., financial support, changing reputation criteria } \\
\text { Inclusion of regional personalities with sustainability expertise in university councils }\end{array}$ \\
\hline
\end{tabular}

\subsection{Establishment of the Sustainable Developmental Role}

From a multilevel perspective, it becomes evident that the establishment of the sustainable developmental results from an interplay of changes on the niche, regime, as well as landscape level of the Higher Education and neighboring systems (see also Figure 2, Table 3).

The regime level in the context of higher education institutions can first be related to how the mainstream of the higher education system currently functions (status quo). At this level, there are a variety of factors that can promote or inhibit a transformation of the understanding of roles vis-à-vis university-region cooperation (the transformation towards a 'sustainable developmental role'). Stephens and Graham [34] mention in this context, among other things, the stability and principles of the various disciplines, the repetitive academic calendar throughout the year, and the independence of the teaching staff. The regime level is located, among other things, by the prevailing educational policy orientation and the expectations of most students regarding their education (cf. below on the concept of landscape in the higher education system). We propose a characterization of the Higher education regime based on five areas. In the status quo, integration between these areas is still low in some cases and takes place primarily under the guiding principle of promoting economic growth, sometimes with a special focus on regional economic growth (see Figure 2).

In the context of MLP, niches are spaces of action in which sustainable practices are experimented with. If we transfer this concept to the cooperation between universities and the region, this includes, for example, groups that implement the concept of the Engaged University, conduct transdisciplinary and transformative research, or the Scientists for Future movement. These do not have to be located at individual universities or in individual regions, but can also be networks of actors in different places. Opportunities for change processes at the level of niches arise both at the level of individual pioneers among researchers and at the level of entire departments and higher education institutions that have adapted their organizational structure and culture of values and their understanding 
of their roles in accordance with the contribution to sustainable regional development [35]. Spatially localized niche dynamics do not necessarily have to come from key actors at the universities themselves. Actors in the spatial environment of the university or other stakeholders can also become driving forces in the development of a 'sustainable developmental role' of universities.

At the level of the higher education system's environment (='landscape' in MLP terms), for example, the freedom of science, the sustainability discourse on the major societal challenges with the Sustainable Development Goals and their implementation at the national level, such as Local Agenda 21 for the municipal level, are to be located. In addition, there is the increased mission orientation of research and innovation policy and new social movements such as 'Fridays for future'.

Regimes and niches of the higher education system are embedded in this environment level, which thus also includes other systems that have an impact on higher education institutions. This also includes the system of higher education and science policy with higher education funding and specific funding programs, which can, for example, set incentives in the direction of sustainable regional development, but also the design of higher education access, as well as fundamental social beliefs and demands on the higher education system [34].

The third mission/transfer is a key interface for cooperation with regional actors and support for sustainable development processes. In this context, the model of the "civic university" developed in the Anglo-American world by Goddard et al. [72] appears to point the way. In this model, boundaries blur both within the university and externally in terms of collaborations with society. The third mission is no longer seen as a third additional task, peripheral or subordinate, while university governance focuses significantly on the core tasks of research and teaching. Rather, interaction with society becomes a unifying dimension between all service areas, and the boundary between higher education, science, and society becomes fluid. The establishment of the 'sustainable (regional) developmental role', thus presupposes a change of model towards the 'civic university' and thus, with regard to the integration of the third mission into the core tasks of a university and its intersection with societal actors outside the subarea of business, clearly goes beyond the model of the 'entrepreneurial university'. Following the model of the 'civic university', cooperation with regional actors becomes an elementary component of the university system in the target scenario (Figure 1, right part). Also integrated into the core is the guiding sustainability concept, which is not only understood as a vague generic term, as is still the case in most university mission statements today [63], but as a scientifically based concept in the sense of the current state of discussion.

\section{Perspectives beyond the MLP (RQ3)}

In connection to the target dimension described qualitatively in Section 3.1, two aspects are elaborated, which have been highlighted in the literature to contribute to a more comprehensive understanding of the universities' sustainable developmental role. That relates to the role of (a) agency [53], and (b) space and place in multiscalar regional transitions towards sustainability $[54,73,74]$. This necessitates to moving beyond the MLP. In doing so, conceptual considerations are also linked to initial empirical evidence.

\subsection{An Agentic Perspective on the Sustainable Developmental Role}

Understanding the sustainable developmental role as the result of complex process dynamics shaped by multiple actors, necessitates a closer examination of the agency. Being aware of the fact that the agentic role of the different levels of government and/or the university management on the one hand and activities and efforts of individual actors inand outside the university play a decisive role [21], a more detailed investigation of the agency deems necessary. In recent years, actors or agents of change at the micro-level, their strategies, resources, and thus, endogenous change dynamics have received increasing attention in transition research $[50,53]$. In this vein, transition researchers are currently 
drawing on approaches from neo-institutional theory to better understand the complex micro-dynamics of transitions.

In transition management, approaches such as institutional entrepreneurship or institutional work are increasingly used to explain the micro-level transition dynamics described above $[53,75,76]$. Actors who "change the rules of the game" by initiating changes that eventually transform existing institutions, or create new ones, have been termed institutional entrepreneurs [77,78], and may range from individuals or groups of individuals [79] to organizations or groups of organizations [80].

Clark [48] suggests that the fundamental change mechanism within 'bottom-heavy' organizations like universities is grassroots innovation, with little interference or steering from managerial structures located at the top. In this vein, Cebrian et al. [32] and Heck [81] argue that IEs within the university can come from any corner of an organization, from senior officials to students, and from academic to administrative staff. As such, "opportunities for agency and possibilities for change have more to do with how one sees oneself within an organization and in relation to others there than the position one holds" [82]. However, empirical findings indicate that institutional entrepreneurs often hold key positions (e.g., department or institute head, professorship, working group leader, leader of the degree program), which allow them to take agency, mobilize resources, and claim support $[21,83]$. This is in line with Battilana et al. [78,84], who refers to the 'social position' of IEs as their formal position with a legitimated identity and access to the resources needed [85]. Empirical evidence confirms that it has often been individual actors within the university who have taken up events at the landscape level, such as the 1992 UN Conference on Environment and Development in Rio de Janeiro, and transferred them to the local context. Such activity we were able to observe, for example, in Freiburg, Darmstadt, and Augsburg [43], whereby, on the one hand, the topic of sustainability was taken up in teaching and research by professors and staff, but by the student council, which organized events in this regard (e.g., Umwelttage Augsburg) and demanded relevant learning content [21].

In the sustainability transitions literature, starting points for change are, however, also identified at the regime level, i.e., within established institutional structures. Referring to the concept of "institutional logics", some authors [86] highlight that socio-technical regimes are usually characterized by different, competing logics. It is argued that the incoherence and tensions this creates in the regime can provide opportunities for "institutional entrepreneurship" and "institutional work" [78,87] activities at the micro-level. These dynamics could be an important starting point for change dynamics, especially in the higher education regime, which is composed of various mutually influencing subsystems and is spatially very heterogeneous (see Section 3). Similarly, Strambach and Pflitsch [88] argue that the strict separation of change and stability in the MLP does not do justice to the complexity of institutional dynamics in regional transition pathways. Instead of the nicheregime dichotomy proposed in the MLP, they refer to the approach of path plasticity [89,90], which assumes that existing structures always contain some room for interpretation, and thus, also starting points for change. Contrary to the assumption that transitions are fundamentally disruptive in character, Mahoney and Thelen [91] refer to neo-institutional theory and assume that even gradual changes can lead to a fundamental change in the longer term. Due to the particularities of the higher education system (including freedom of research and teaching, flat hierarchies), it can be assumed that it is precisely here that actors can also implement new sustainability-oriented projects directly within the existing regime, and thus, initiate gradual changes that "add up" to a more fundamental change in the long run. An example for this can be found in the Augsburg region, where actors at both the university and in the region used the designation of Augsburg as an environmental competence region to initiate a thematically broad sustainability transition process also incorporating social, economic, and cultural aspects of sustainability [21]. Hume [35] and Deleye [46] also already point out in their studies that the changeability of the regime (especially in the higher education sector) is underestimated [91]. 
Stephens and Graham [34] highlight four different governance activities (strategic, tactical, operational, reflexive) that can drive such a transition, and they distinguish four phases (predevelopment, take-off, breakthrough, stabilization) of such a transition. Strategic activities particularly require leadership and vision creation at the university leadership and policy levels which tend to be top-down driven activities. Several authors $[33,34,44,92,93]$ highlight the crucial role of university leadership in promoting sustainability via visioning, laying out long-term system-level goals and objectives, and establishing the structure and context for change. Due to the fragmented organizational structure, as well as the high person-boundedness of sustainability-related bottom-up activities, top-down consolidation via institutionalization is important to legitimize these changes. Examples of this are the interdisciplinary Research Center for the Environment (WZU) at the University of Augsburg or the interdisciplinary energy institute at the Johannes Kepler University Linz [21,44]. Tactically, it is mainly about building alliances with actors from other sectors of society that can provide important impetus for change. Regional actors and alliances come to mind here, for example. Operationally, it is about implementing projects, and in the case of reflexive activities, about the reflection of progress by the university itself [34]. Overall, the literature shows that there are many good projects within universities and that many value-driven individual actors show an extraordinary commitment. But ultimately, at some point, a limit to this bottom-up driven process seems to be reached. Hume [35] concludes in her research that there is still a lack of long-term support for these individual activities in the higher education systems studied by her, i.e., Northern Ireland and the Republic of Ireland. There is no long-term perspective, no vision, no leadership at the level of university management and policy. The case studies on Augsburg and Linz [21] come to similar conclusions, as does a study by the Center for Higher Education Development [63]. This supports the development described in the target scenario that bottom-up processes should be supported top-down by sustainability-oriented, participatory university governance (see Section 3.1, Table 3) to establish 'down-up' processes.

\subsection{The Role of Space and Place for the Establishment of the Sustainable Developmental Role}

The literature on the geography of sustainability transitions has generated valuable insights into the role of space and place in socio-technical transitions. In this context, the place-specificity of transitions, as well as their multiscalar character, is emphasized [55,56]. For example, studies highlight that sustainability transitions are strongly influenced by the formal and informal institutional environment in a region [88], technological and industrial specialization [94,95]; the availability of certain natural resources [8], and the development of regional markets [8]. Moreover, transitions at the local level are shaped by various forms of spatial and relational proximity. Studies show that this proximity can have a beneficial effect on the collaboration of different groups of actors within a socio-technical system [96]. However, in addition to the place specificity of transitions, the multiscalar character of transitions is also emphasized at the same time. Current approaches even argue that transitions are not primarily shaped by local path dependencies, but have a strong global character in many sectors [58]. The increasingly international actor networks that drive the diffusion of global regime rationalities are seen as the reason for this.

Based on findings from the geography of transitions research field $[55,56]$ it can be assumed that higher education institutions and their spatial environment mutually influence their transformation and that these processes are, thus, "place-specific" [21]. Grillitsch and Sotarauta [97] add to this that actors are embedded in an 'opportunity space' that is specific to a given region and time. However, most studies in the literature on HEIs and sustainability transitions only address the transformation of the HEI itself, and thus, neglect the interdependencies between HEIs and their regional surrounding.

Radinger-Peer and Pflitsch [44] show that it is difficult to distinguish between the transition of the university and the transition by the university. Among other things, there are strong interactions with the regional environment here. The respective university region has a strong influence on the university and its transition towards sustainability. 
Conceptual elaboration of this interaction has great potential to be an important extension of previous MLPs and contributes to a better understanding of the geography of sustainability transformation.

Socio-economic and structural preconditions such as the industrial basis, demography, economic performance, natural resource endowments, regional absorptive capacity, and infrastructure shape the place-specific university-region setting. In addition, the relational proximity of IEs to public and private actors has been highlighted as key for enacting institutional and organizational change [98]. This includes organizational proximity, which influences the university's participation in networks and regional strategy processes, but also cognitive proximity, which affects the potential for joint knowledge creation and cooperation, as well as social proximity on the micro level, which refers to relations based on trust, friendship, and experience. Relational proximity is affected by the founding history of the university and the record of the university-region interaction, as well as regional expectations towards the university [99].

Thus, the present and future impact of universities on sustainable regional development is also shaped by the history and former experiences of the university-region connections [30]. At the same time, it must be acknowledged that the transformation of HEIs is characterized by the interplay of actors at multiple spatial scales. The complex multiscalar dynamics of sustainability transitions, which have been elaborated in geographical transition research $[57,58]$, are also not examined more closely in previous research on higher education institutions and MLP. This is astonishing regarding the potential of universities to bring together heterogeneous actors and discourses, even across different spatial levels, and thus, become local-global nodes [35].

The relevance of such a geographical perspective for the analysis of the transformation of the higher education system towards a "sustainable developmental role", is already evident in the studies of Pflitsch and Radinger-Peer [21] and Hume [35]. In their comparative case study, Pflitsch and Radinger-Peer [21] show that transformations in higher education institutions are strongly shaped by site-specific path dependencies (among other things, they highlight the historically grown networks and the institutional environment in the region as important influencing factors in this context). In contrast, Hume's [35] case study illustrates that the local transformations of the two HEIs are also significantly shaped by dynamics at a global regime level and that local "change agents", therefore, also need to collaborate with actors at other spatial levels to drive change at their HEI. A deeper examination of the spatial dynamics underlying a transition of the higher education system towards a "sustainable developmental role", therefore, seems necessary. In order to better understand the drivers and barriers of these processes, it is essential to analyze the interaction of global and local dynamics in the higher education system and at the interface between higher education institutions and their regional environment.

\section{Discussion and Conclusions}

The paper has discussed the suitability of the MLP to study the transition of universities and university systems towards a sustainable developmental role in the regional context. Based on an analysis of the conceptual literature and examples from own empirical work, the MLP has been applied to the higher education system, especially to conceptualize the transition of universities towards a sustainable (regional) developmental role. It has been found that the MLP alone is insufficient to fully understand the sustainable developmental role of universities. Thus, three additional perspectives have been identified and conceptualized: (a) The target dimension of sustainable regional development, (b) the role of agency, and (c) the introduction of space and place to multiscalar regional transitions.

The main contribution of the paper and its predominant impact on the field is a more balanced and specified version of the MLP, which can be used to analyze how universities establish their sustainable developmental role in the regional context. The introduction of a target dimension for the transition of universities towards sustainable regional development is an important addition to the existing literature. Based on this target 
dimension, the conceptual debate is extended beyond the established MLP by introducing the role of agency and new perspectives on space and place.

The main theoretical implication of the paper is a better understanding of the transition processes of universities and higher education systems. It has been found that the MLP, in general, has the potential to improve our conceptual understanding of the transformation processes of universities. However, certain particularities of the university system need to be considered to adapt the general MLP perspective in a meaningful way. This process of conceptual adaption is still in its infancy. We suggest that the following particularities at the three levels are relevant starting points to further sharpen the MLP lens for its application to university systems: (i) Freedom of research and teaching, subject-specific traditions (landscape level), (ii) guiding principles (e.g., entrepreneurial university), weakly developed hierarchies, 'loosely coupled systems', and global 'epistemic communities' (at the regime level), (iii) a high degree of autonomy at the level of individual researchers and working groups (at the niche level).

Furthermore, the conceptual discussion and empirical illustrations in this paper have shown that despite being a suitable starting point, the MLP possesses some limitations to fully cover the complexities of universities and university systems with regard to a transition towards a sustainable (regional) developmental role. These limitations are, in particular, related to (a) the target dimension of sustainable regional development, (b) the role of agency, and (c) the introduction of space and place to multiscalar regional transitions.

A vague definition of the target dimension for the transition process and the direction of change within socio-technical systems have been identified as limitations in the MLP literature. In this particular paper, 'sustainable regional development' has been specified as the target dimension for a sustainability transition of universities and university systems. The paper has provided a target scenario for sustainable regional development that considers its substantial, procedural, actor-related, spatial, and temporal dimensions. Based on an extensive literature review, characteristics are provided regarding how the sustainable (regional) developmental role of universities can be established in the fields of research, teaching, third mission/transfer/engagement, university operations, and university governance. Potential constellations of an interplay of changes at the niche, regime, and landscape level for establishing the sustainable developmental role of universities have been discussed, too.

A nuanced understanding of agency has been a blind spot in the MLP for a long time, but it is a particular importance when analyzing the transition of universities and university systems. Based on an analysis of some initial studies which focus on the role of agency in the transition of universities it has been found that many value-driven individual actors show an extraordinary commitment within universities and that their action has been decisive for sustainability outcomes. But ultimately, at some point, a limit to this bottom-up driven process seems to be reached, and long-term organizational support for these individual activities is required at the level of particular universities, as outlined in the target scenario with the establishment of sustainable governance, and at the systemic level in general.

Issues related to space and place have been discussed in the MLP community for some years now, and the "Geographies of Sustainability Transitions" (GOST) have provided important insights to MLP from a spatial perspective. Nevertheless, an in-depth understanding of space and place gains even more importance if the analytical focus is on processes of embeddedness of universities in multiscalar transitions of "their" region. It has been shown that the interface between universities and their regional environment is complex and of an interactive nature. It is, therefore, difficult to distinguish between the transition of the university and the transition by the university. Transition topologies are identified as a starting point to analyze these complexities by taking into account the dimensions of space and place. Such an actor-centered and place-based analysis of transitions at the interface of universities and their regional context should also take the 
role of external practices into account, e.g., regional change agents, which have an impact on the university transition.

Finally, the abovementioned conceptual developments in transition studies and the additions to the literature provided in this paper also require new methodological approaches for studying the establishment of the sustainable developmental role of universities in the regional context. In future empirical studies, discourse analytical methods could be used even more intensely and in combination with network analysis, to map the institutional and multiscalar dynamics of transitions [100]. In addition, processes tracing approaches are growing in importance, such as 'transition topologies [88], in which transitions are mapped over time using organizational and associated institutional changes. Pflitsch and Radinger-Peer [21] are already using this approach to show how relationships between universities and their regional context need to change and expand for universities to take on their 'sustainable developmental role'.

With regard to the conceptual and practical implications of this paper, it has been found that the self-perception and structure of individual universities play an important role in niche activities. Further empirical research can help to distinguish different strategies and transition paths, and enrich the literature by a more comprehensive elaboration. There is still a great need for research in this topic area, as systematic and comparative work on higher education systems from this conceptual perspective has been lacking so far. The paper has outlined potential pathways for better capturing the transition capabilities of universities and university systems analytically with regard to their 'sustainable (regional) developmental role'. While the MLP could be used as a conceptual lens in general, it should be supplemented by a better specification of the target dimension of the transition, an agency perspective, and more careful consideration of the multiscalar spatial logic of transitions, which also takes the influence of external practices in the respective region into account. Discourse analytical methods, network analyses, and process tracing approaches should complement the existing set of methods for studying transitions of universities in their region.

Finally, the findings possess practical implications for university administrators and regional development managers. University administrators could proactively support niches in the university and develop incentive systems for the regional sustainable developmental role jointly with higher education policymakers. Transition management techniques have the potential to reconcile niche and regime actors within the university. Regional development managers at the municipal level could jointly develop regional sustainability strategies in close cooperation with change agents at the university.

Author Contributions: Conceptualization, V.R.-P., G.P., H.K., D.S. methodology, V.R.-P., G.P., H.K., D.S.; data curation, V.R.-P., G.P.; writing—original draft preparation, V.R.-P., G.P., H.K.; writingreview and editing, V.R.-P., G.P., H.K., D.S.; visualization, V.R.-P.; supervision, D.S. All authors have read and agreed to the published version of the manuscript.

Funding: This research was partially funded by the Austrian Science Fund FWF, grant number T761-G21.

Institutional Review Board Statement: Not applicable.

Informed Consent Statement: Not applicable.

Data Availability Statement: Not applicable.

Acknowledgments: The authors would like to thank the ARL (Akademie für Raumentwicklung in der Leibniz Gesellschaft) which initiated the working group "Universities and sustainable regional development". The discussions and joint publication of the authors in the frame of this working group formed the basis for the present article.

Conflicts of Interest: The authors declare no conflict of interest. 


\section{References}

1. Benneworth, P. Characterising Modes of University Engagement with Wider Society. A Literatuer Review and Survey of Best Practice; Newcastle University: Newcastle Upon Tyne, UK, 2009.

2. Gunasekara, C. The Generative and Development Roles of Universities in Regional Innovation Systems. Sci. Public Policy 2006, 33, 137-150. [CrossRef]

3. Etzkowitz, H.; Leydesdorff, L. (Eds.) Introduction: Universities in the GLobal Knowledge Economy. In Universities and the Global Knowledge Economy: A Triple Helix of Uniersity-Industry-Government Relations; Pinter: London, UK, 2017; pp. 1-8.

4. Perkmann, M.; Tartari, V.; McKelvey, M.; Autio, E. Academic Engagement and Commercialisation: A Review of the Literature on University-Industry Relations. Res. Policy 2013, 42, 423-442. [CrossRef]

5. Boucher, G.; Conway, C.; Van der Meer, E. Tiers of Engagement by Unviersiteis in Their Region's Develoment. Reg. Stud. 2003, 37, 887-897. [CrossRef]

6. Chatterton, P.; Goddard, J. The Response of Higher Education Institutions to Regional Needs. Eur. J. Educ. 2000, 35, 475-496. [CrossRef]

7. Arbo, P.; Benneworth, P. Understanding the Regional Contribution of Higher Education Institutions: A Literature Review; Education Working Paper; OECD: Paris, France, 2007.

8. Späth, P.; Rohracher, H. Local Demonstrations for Global Transitions-Dynamics across Governance Levesl Fostering SocioTechincal Regime Change towards Sustainability. Eur. Plan. Stud. 2012, 20, 461-479. [CrossRef]

9. WCED. Our Common Future; Oxford University Press: Oxford, UK, 1987.

10. UN. United Nations Conference on Environment and Development. Agenda 21; United Nations: Rio de Janeiro, Brazil, 1992.

11. UN. Transforming Our World: The 2030 Agenda for Sustainable Development. A/RES/70/1; United Nations: New York, NY, USA, 2015.

12. Lozano, R. Incorporation and Institutionalization of SD into Unviersities: Breaking through Barriers to Change. J. Clean. Prod. 2006, 14, 787-796. [CrossRef]

13. Aras, G.; Crowther, D. Governance and Sustainability: An Investigation into the Relationship between Cororate Governance and Corporate Sustainability. Manag. Decis. 2008, 46, 433-448. [CrossRef]

14. Zadek, S. The Logic of Collabrative Governance: Corporate Responsibility, Accountability and the Social Contract; John, F., Ed.; Corporate Social Responsibility Initiative; Kennedy School of Government, Harvard University: Cambridge, MA, USA, 2006.

15. Lozano, R. The State of Sustainablity Reporting in Universities. Int. J. Sustain. High. Educ. 2011, 12, 67-78. [CrossRef]

16. Cortese, A.D. The Critical Role of Higher Education in Creating a Sustainable Future. Plan. High. Educ. 2003, $31,15-22$.

17. Dlouha, J.; Barton, A.; Huisingh, D.; Adomssent, M. Learning for Sustainable Development in Regional Networks. J. Clean. Prod. 2013, 49, 1-4. [CrossRef]

18. Lee, Y.S.; Schottenfeld, M.A. Internationalising Experiential Learning for Sustainable Development Education. J. Educ. Sustain. Dev. 2012, 6, 341-354. [CrossRef]

19. Filho, W.L. About the Role of Universities and Their Contribution to Sustainable Development. High. Educ. Policy 2011, 24, 427-438. [CrossRef]

20. Waas, T.; Verbruggen, A.; Wright, T. University Research for Sustainable Development: Definition and Characteristics Explored. J. Clean. Prod. 2010, 18, 629-636. [CrossRef]

21. Pflitsch, G.; Radinger-Peer, V. Developing Boundary-Spanning Capacity for Regional Sustainability Transition-A Comparative Case Study of the Universities of Augsburg (Germany) and Linz (Austria). Sustainability 2018, 10, 918. [CrossRef]

22. Zilahy, G.; Huisingh, D.; Melanen, M.; Philips, V.; Sheffy, J. Roles of Academia in Regional Sustainability Initiatives: Outreach for a More Sustainable Future. J. Clean. Prod. 2009, 17, 1053-1056. [CrossRef]

23. Adomssent, M.; Godemann, J.; Michelsen, G. Transferability of Approaches to Sustainable Developmetn at Universities as a Challenge. Int. J. Sustain. High. Educ. 2007, 8, 385-402. [CrossRef]

24. Velazquez, L.; Munuia, N.; Platt, A. Sustainable University: What Can Be the Matter? J. Clean. Prod. 2006, 14, 810-819. [CrossRef]

25. Trencher, G.; Yarime, M.; McCormick, K.B.; Doll, C.; Kraines, S. Beyond the Third Mission: Exploring the Emerging University Function of Co-Creation for Sustainability. J. Clean. Prod. 2014, 41, 151-179. [CrossRef]

26. Zilahy, G.; Huisingh, D. The Roles of Academia in Regional Sustainability Initiatives. J. Clean. Prod. 2009, 17, 1057-1066. [CrossRef]

27. Beynaghi, A.; Trencher, G.; Moztarzadeh, F.; Mozafari, M.; Maknoon, R.; Filho, W. Future Sustainability Scenarios for Universities: Moving beyond the United Nations Decade of Education for Sustainable Development. J. Clean. Prod. 2016, 112, $3464-3478$. [CrossRef]

28. Caniels, M.; van den Bosch, H. The Role of Higher Education Institutions in Building Regional Innovation Systems. Pap. Reg. Sci. 2011, 90, 271-286. [CrossRef]

29. Scholz, R. Transdisciplinarity: Science for and with Society in Light of the University's Roles and Functions. Sustain. Sci. 2020, 1033-1049. [CrossRef]

30. Spekkink, W.; Boons, F. The Emergence of Collaborations. J. Public Adm. Res. Theory 2015, 613-630. [CrossRef]

31. Kanning, H.; Schiller, D. Engagierte Hochschulen. Pioniere Des Wandels Für Nachhaltige Regionalentwicklungen? Unimagazin (Forschungsmagazin der Leibniz Universität Hannover) 2014, 3/4, 30-32.

32. Cebrian, G.; Grace, M.; Humphris, D. Organisational Learning towards Sustainability in Higher Education. Sustain. Account. Manag. Policy J. 2013, 4, 285-306. [CrossRef] 
33. Blanco-Portela, N.; Benayas, J.; Pertierra, L.; Lozano, R. Towards the Integration of Sustainability in Higher Education Institutions: A Review of Drivers and Barriers to Organisational Change and Their Comparison against Those Found of Companies. J. Clean. Prod. 2017, 166, 563-578. [CrossRef]

34. Stephens, J.C.; Graham, A.C. Toward an Empirical Research Agenda for Sustainaibility in Higher Education: Exploring the Transition Management Framework. J. Clean. Prod. 2010, 18, 611-618. [CrossRef]

35. Hume, M.T. Higher Education and the Transition to a Sustainable Future; School of Politics, International Studies and Philosophy Queen's University Belfast: Belfast, UK, 2015.

36. Rip, A.; Kemp, R. Technological Change. In Human Choice and Climate Change; Malone, E.L., Ed.; Battelle Press: Columbus, OH, USA, 1998; pp. 327-399.

37. Geels, F. Technological Transition as Evolutionary Configuration Processes: A Multi-Level Perspective and a Case-Study. Res. Policy 2002, 31, 1257-1274. [CrossRef]

38. Geels, F.W. From Sectoral Systems of Innovation to Socio-Technical Systems. Insights about Synamics and Change from Sociology and Institutional Theory. Res. Policy 2004, 33, 897-920. [CrossRef]

39. Markard, J.; Raven, R.; Truffer, B. Sustainability Transitions: An Emerging Field of Research and Its Prospects. Res. Policy 2012, 41, 955-967. [CrossRef]

40. Wolfram, M.; Frantzeskaki, N. Cities and Systemic Change for Sustainability: Prevailing Epistemologies and an Emerging Research Agenda. Sustainability 2016, 8, 144. [CrossRef]

41. Geels, F.W. The Multi-Level Perspective on Sustainability Transitions: Responses to Seven Criticisms. Environ. Innov. Soc. Transit. 2011, 1, 24-40. [CrossRef]

42. Schiller, D.; Kanning, H.; Pflitsch, G.; Radinger-Peer, V.; Freytag, T. Hochschulen Und Nachhaltige Regionalentwicklung Aus Der Transitions-Perspektive; Hochschulen und nachhaltige Regionalentwicklung, Forschungsbereicht der ARL, Sammelband der Ergebnisse des ARL Abreitskreises; Verlag der ARL-Akademie für Raumforschung und Landesplanung: Hannover, Germany, 2020.

43. Radinger-Peer, V.; Pflitsch, G.; Freytag, T.; Döring, T. Transformationsprozesse Im Hochschulsystem in Richtung Nachhaltige Regionalentwicklung ("Empirische Illustrationen"); Hochschulen und nachhaltige Regionalentwicklung, Forschungsbereicht der ARL, Sammelband der Ergebnisse des ARL Abreitskreises; Verlag der ARL-Akademie für Raumforschung und Landesplanung: Hannover, Germany, 2020.

44. Radinger-Peer, V.; Pflitsch, G. The Role of Higher Education Institutions in Regional Transition Paths towards Sustainability. The Case of Linz (Austria). Rev. Reg. Res. 2017, 37, 161-187. [CrossRef]

45. Strambach, S.; Pflitsch, G. Micro-Dynamics in Regional Transition Paths to Sustainability—Insights from the Augsburg Region. Appl. Geogr. 2018, 90, 296-307. [CrossRef]

46. Deleye, M.; van Poeck, K.; Block, T. Lock-Ins and Opportunities for Sustainability Transitions. A Multi-Level Analysis Fo the Flemish Higher Education System. Int. J. Sustain. High. Educ. 2019, 20, 1109-1124. [CrossRef]

47. Weick, K.E. Educational Organizations as Loosely Coupled Systems. Adm. Sci. Q. 1976, 21, 1-19. [CrossRef]

48. Clark, B.R. The Higher Education System: Academic Organization in Cross-National Perspective; University of California Press: Berkeley, CA, USA, 1983.

49. Geels, F.W.; Schot, J. Typology of Sociotechnical Transition Pathways. Res. Policy 2007, 36, 399-417. [CrossRef]

50. Geels, F.; Kern, F.; Fuchs, G.; Hinderer, N.; Kungl, G.; Mylan, J.; Neukirch, M.; Wassermann, S. The Enactment of Socio-Technical Transition Pathways: A Reformulated Typology and a Comparative Multi-Level Analysis of the German and UK Low-Carbon Electricity Transitions (1990-2014). Res. Policy 2016, 45, 896-913. [CrossRef]

51. de Haan, J.; Rotmans, J. Patterns in Transitions: Understanding Complex Chains of Change. Technol. Forecast. Soc. Chang. 2011, 78, 90-102. [CrossRef]

52. Shove, E.; Walker, G. Governing Transitions in the Sustainability of Everyday Life. Res. Policy 2010, 39, 471-476. [CrossRef]

53. Farla, J.; Markard, J.; Raven, R.; Coenen, L. Sustainability Transitions in the Making: A Closer Look at Actors, Strategies and Resources. Technol. Forecast. Soc. Chang. 2012, 79, 991-998. [CrossRef]

54. Truffer, B.; Coenen, L. Environmental Innovation and Sustainability Transitions in Regional Studies. Reg. Stud. 2012, 46, 1-21. [CrossRef]

55. Hansen, T.; Coenen, L. The Geography of Sustainablity Transitions: Review, Synthesis and Reflections on an Emergent Research Field. Environ. Innov. Soc. Transit. 2015, 17, 92-109. [CrossRef]

56. Binz, C.; Coenen, L.; Murhpy, J.; Truffer, B. Geographies of Transition-From Topical Concerns to Theoreticalengagement: A Commentary on the Transitions Research Agenda. Environ. Innov. Soc. Transit. 2020, 34, 1-3. [CrossRef]

57. Sengers, F.; Raven, R.P. Toward a Spatial Perspective on Niche Development: The Case of Bus Rapid Transit. Environ. Innov. Soc. Transit. 2015, 166-182. [CrossRef]

58. Fuenfschilling, L.; Binz, C. Gobal Socio-Technical Regimes. Res. Policy 2018, 47, 735-749. [CrossRef]

59. Spehl, H. Nachhaltige Raumentwicklung. In Handwörterbuch der Raumplanung; ARL Akedemie für Raumforschung und Landesplanung: Hannover, Germany, 2005; pp. 679-685.

60. Hofmeister, S. Nachhaltigkeit. Vorabveröffentlichung. In Handwörterbuch der Stadt- und Raumentwicklung; ARL Akedemie für Raumforschung und Landesplanung: Hannover, Germany, 2017. 
61. Hofmeister, S. Das Leitbild Nachhaltigkeit-Anforderungen an die Raum- und Umweltplanung. Öffentliche Nachhaltigkeitssteuerung. In Nachhaltigkeitswissenschaften; Heinrichs, H., MIchelsen, G., Eds.; Springer: Berlin/Heidelberg, Germany; New York, NY, USA, 2014; pp. 304-320.

62. Hübler, K.H.; Kaether, J.; Selwig, J.; Weiland, U. Weiterentwicklung Und Präzisierung Des Leitbildes Der Nachhaltigen Entwicklung in Der Regionalplanung Und Regionalen Entwicklungskonzepten; Umweltbundesamt: Berlin, Germany, 2000.

63. Stuckrad, T.; Röwert, R. Themenfelder Als Profilbildungselement and Deutschen Hochschulen: Trendanalyse Und Themenkarte; Arbeitspapier Des Centrums Für Hochschulentwicklung (CHE): Gütersloh, Germany, 2017.

64. WBGU Wissenschaftlicher Beirat der Bundesregierung globale Umweltveränderung Hauptgutachten. Welt Im WandelGesellschaftsvertrag für Eine Große Transformation. Zusammenfassung für Entscheidungsträger; WBGU: Berlin, Germany, 2011.

65. WR. Wissens-Und Technologietransfer Als Gegenstand Institutioneller Strategien. Positionspapier; WR: Koln, Germany, 2016; p. 5665-16.

66. Brand, K.-W. Nachhaltigkeitsforschung-Besonderheiten, Probleme und Erfordernisse eines neuen Forschungstypus. In Nachhaltige Entwicklung und Transdisziplinarität; Brand, K.-W., Ed.; GBV: Berlin, Germany, 2000; Volume 16, pp. 9-28.

67. Becker, E.; Jahn, T. (Eds.) Soziale Ökologie: Grundzüge Einer Wissenschaft von Den Gesellschaftlichen Nahverhältnissen; Campus Verlag: Frankfurt, Germany; New York, NY, USA, 2006.

68. Wiek, A.; Withycombe, L.; Redman, C.L. Key Competencies in Sustainablity: A Reference Framework for Academic Program Development. Sustain. Sci. 2011, 6, 203-2018. [CrossRef]

69. Kanning, H.; Kurz, R.; Twarok, J. Zivilgesellschaftliche Impulse Für Das Hochschulsystem: Zur Rolle Der Hochschulräte. Die neue Hochschule 2016, 6, 182-185.

70. Schneidewind, U.; Singer-Brodowksi, M. Transformative Wissenschaft. Klimawandel Im Deutschen Wissenschafts- Und Hochschulsystem; Metropolis-Verlag: Marburg, Germany, 2013.

71. Henke, J.; Pasternack, P.; Schmid, S. Third Mission Bilanzieren. Die Dritte Aufgabe der Hochschulen und Ihre Öffentliche Kommunikation; Die Hochschule HoF-Handreichungen, Beiheft; Institut für Hochschulforschung (HoF): Wittenberg, Germany, 2016.

72. Goddard, J.; Hazelkorn, E.; Kempton, L.; Vallance, P. The Civic University. The Policy and Leadership Challenges; Edward Elgar Publishing: Celtenham, UK; Northampton, UK, 2016.

73. Murphy, J.T. Human Geography and Socio-Technical Transition Studies: Promising Intersections. Environ. Innov. Soc. Transit. 2015, 17, 73-91. [CrossRef]

74. Smith, A.; Raven, R. Waht Is Protective Space? Rescondiersing Niches in Transitions to Sustainability. Res. Policy 2012, 41, 1025-1036. [CrossRef]

75. Giddens, A. The Constitution of Society: Outline of the Theory of Structuration; Polity Press: Cambridge, UK, 2007.

76. Loorbach, D.; Frantzeskaki, N.; Avelino, F. Sustainability Transitions Research: Transforming Science and Practice for Societal Change. Annu. Rev. Environ. Resour. 2017, 42, 599-626. [CrossRef]

77. Di Maggio, P.J. Interest and agency in institutional theory. In Institutional Patterns and Organizations; Zucker, L., Ed.; Ballinger: Cambridge, MA, USA, 1988; pp. 3-22.

78. Battilana, J. Agency and Institutions: The Enabling Role of Individuals' Social Position. Organization 2006, 13, 653-676. [CrossRef]

79. Fligstein, N. Social Skill and Institutional Theory. Am. Behav. Sci. 1997, 40, 397-405. [CrossRef]

80. Greenwood, R.; Suddaby, R. Institutional Entrepreneurship in Mature Fields: The Big Five Accounting Firms. Acad. Manag. J. 2006, 49, 27-48. [CrossRef]

81. Heck, D. Institutionalizing Sustainability: The Case of Sustainability at Griffith University Australia. Appl. Environ. Educ. Commun. 2005, 4, 55-64. [CrossRef]

82. Barlett, P.; Chase, G. (Eds.) Sustainability on Campus, Stories and Strategies for Change; MIT Press: Cambridge, MA, USA, 2004.

83. Sedlacek, S. The Role of Universities in Fostering Sustainable Development at the Regional Level. J. Clean. Prod. 2013, 48, 74-84. [CrossRef]

84. Battilana, J.; Leca, B.; Boxenbaum, E. How Actors Change Institutions: Towards a Theory of Institutional Entrepreneurship. Acad. Manag. Ann. 2009, 3, 65-107. [CrossRef]

85. Lawrence, T.B. Institutional Strategy. J. Manag. 1999, 25, 161-188.

86. Thornton, P.; Ocasio, W. Institutional Logics. In SAGE Handbook of Organizational Institutionalism; Greenwood, R., Oliver, C., Suddaby, R., Sahlin-Andersson, K., Eds.; Sage: London, UK; Thoursand Oaks, CA, USA, 2008.

87. Lawrence, T.B.; Suddaby, R. Institutions and institutional work. In Sage Handbook of Organization Studies; Stewart, R., Hardy, C., Lawrence, T.B., Nord, W., Eds.; Sage: London, UK, 2006; pp. 215-254.

88. Strambach, S.; Pflitsch, G. Transition Topology: Capturing Institutional Dynamics in Regional Development Paths to Sustainability. Res. Policy 2020. [CrossRef]

89. Strambach, S. Path dependence and path plasticity. In The Handbook of Evolutionary Economic Geography; Boschma, R., Martin, R., Eds.; Edward Elgar Publishing Limited: Celtenham, UK, 2010; pp. 406-431.

90. Strambach, S.; Halkier, H. Reconceptualizing Change-Path Dependency, Path Plasticity and Knowledge Combination. Z. Wirtsch. 2013, 57, 1-14. [CrossRef]

91. Mahoney, J.; Thelen, K. (Eds.) A theory of graudal institutional change. In Explaining Institutional Change. Ambiguity, Agency and Power; Cambridge University Press: New York, NY, USA, 2010. 
92. Goldstein, H.; Radinger-Peer, V.; Sedlacek, S. The Pathways and Challenges of University Engagement: Comparative Case Studies. In Handbook of Universities and Regional Development; Varga, A., Erdos, K., Eds.; Edward Elgar Publishing: Celtenham, UK, 2019.

93. Lozano, R.; Lukman, R.; Lozano, F.; Huisingh, D.; Lambrechts, W. Declarations for Sustainability in Higher Education: Becoming Better Leaders, through Addressing the University System. J. Clean. Prod. 2013, 48, 10-19. [CrossRef]

94. Carvalho, L.; Mingardo, G.; Van Haaren, J. Green Urban Transport Policies and Cleantech Innovations: Evidence from Curitiba, Göteborg and Hamburg. Eur. Plan. Stud. 2012, 20, 375-396. [CrossRef]

95. Gibbs, D.; O'Neill, K. Rethinking Sociotechnical Transitions and Green Entrepreneurship: The Potential for Transformative Change in the Green Building Sector. Environ. Plan. A 2014, 46, 1088-1107. [CrossRef]

96. Mattes, J. Dimensions of Proximity and Knowledge Bases: Innovation between Spatial and Non-Spatial Factors. Reg. Stud. 2012, 46, 1085-1099. [CrossRef]

97. Grillitsch, M.; Sotarauta, M. Trinity of Change Agency, Regional Developmen Aths and Opportunity Spaces. Prog. Hum. Geogr. 2019, 44, 1-20.

98. Fullan, M.; Scott, G. Turnaround Leadership for Higher Education; Jossey-Bass: San Francisco, CA, USA, 2009.

99. Boschma, R.A. Proximity and Innovation. A Critical Assessment. Reg. Stud. 2005, 39, 61-74. [CrossRef]

100. Heiberg, J.; Binz, C.; Truffer, B. The Geography of Technology Legitimation: How Multiscalar Institutional Dynamics Matter for Path Creation in Emerging Industries. Econ. Geogr. 2020, 96, 470-498. [CrossRef] 